Wiśniewska, A. (2018). The Initial Coin Offering - challenges and opportunities. Copernican Journal of Finance \& Accounting, 7(2), 99-110. http://dx.doi.org/10.12775/CJFA.2018.011

\author{
ANNA WiŚNIEWSKA* \\ Nicolaus Copernicus University in Toruń
}

\title{
THE INITIAL COIN OFFERING - CHALLENGES AND OPPORTUNITIES
}

Keywords: cryptocurrencies, tokens, initial coin offering, corporate finance.

J E L Classification: G15, G19, G30.

\begin{abstract}
The research objective of the article: The aim of the paper is to present the challenges and opportunities of Initial Coin Offering (ICO) procedure (sometimes appearing in literature and official documents as the Initial Token Offering (ITO)) from the point of view of a company as well as verify the hypothesis about ICO as a cheap form of capital rising that is often presented in websites dedicated to ICO. There are enumerated the differences and similarities to the Initial Public Offering and possible advantages over other methods of capital rising. The paper points out the most important barriers to the use of ICO. The research method applied: As there is shortage of available research papers and literature related to the topic that are focused on financial aspects such as comparison between ICO and other methods of capital rising, there was conducted the analysis of reliable internet sources and a case study method of Ethereum - the first company that applied the Initial Coin Offering procedure. The mentioned research method has its limits, as it is necessary to verify received information. That is the reason why only professional websites dedicated to the topic were used. The outcome of the research (considerations, analyses), main conclusion(s): the Initial Coin Offering procedure is recognised as a very controversial topic. It is clearly visible that ICO has many advantages over traditional forms of rising capital for the company, but, so far, ambiguous legal status, cost level and high risk of scams and other possible abuses make it difficult to become widely applied by newly created companies.
\end{abstract}

Date of submission: May 14, 2018; date of acceptance: June 5, 2018.

* Contact information: amw@doktorant.umk.pl, Faculty of Economic Sciences and Management, Nicolaus Copernicus University in Toruń, Gagrina 13a, 87-100 Toruń, Poland, phone: 693411 309; ORCID ID: https://orcid.org/0000-0002-0512-4550. 


\section{INTRODUCTION}

The cryptocurrency market has been developing rapidly since its beginning in 2009, when Satoshi Nakamoto launched the Bitcoin system, previously described in the paper named: "Bitcoin: a peer-to-peer electronic cash system" that was published online in 2008 and since then, has been sometimes called "the manifesto" by the Bitcoin community. Although cryptocurrencies were primarily expected to become a form of money, and further to be an official currency of the internet, the Initial Coin Offering popularity in 2017 seems to deny that view. The lack of fulfilling money functions, such as being an unit of account, a medium of exchange, a store of value and a standard of deferred payment, as well as the predominant role of speculative motive of keeping money and, above all, not being widely accepted as a form of payment, are the key arguments that do not allow to consider cryptocurrencies to be money in general. However, some of them, like bitcoin or litecoin, are sometimes used as a form of payment.

Entrepreneurs, per definition, could be characterized as innovators. It is not surprising that some of them noticed possible applications of cryptocurrencies and the blockchain technology. The Initial Coin Offering is one of that applications. It allows companies, mostly start-ups, to finance their projects. The procedure can be defined as the method of raising capital by an organisation or individual by the emission of cryptocurrency or token (ESMA, 2017, p. 2). The aim of the paper is to present the Initial Coin Offering (ICO) procedure as well as its challenges and opportunities from the point of view of a company and also governmental authorities.

\section{THE RESEARCH METHODOLOGY AND THE COURSE OF THE RESEARCH PROCESS}

To reach the aim of the study there was applied the analysis of existing literature and research papers connected with cryptocurrency market. Most of research papers related to the topic are concentrated to legal aspects of ICO. Because of a shortage of that kind of sources about the Initial Coin Offering that focus on financial aspects, there were used information published by reliable websites that specialize in ICO and cryptocurrencies. The method that was used has its limits among which the most important one is the necessity to verify information and a fact that it can have a subjective character, as websites 
are conducted by cryptocurrencies' proponents. That is the reason why official statements published by The National Bank of Poland and European Securities and Markets Authority were also included in the research process.

To complement the desk research method the single case study of the Ethereum project was employed. Ethereum was the first organization that applied the Initial Coin Offering procedure to raise capital. Its experiences within successful ICO procedure help to understand the challenges that companies which want to apply the procedure must face. Main difficulties connected with using the case study method are those related to making generalisation and verifying information from the official website.

\section{THE OUTCOME OF THE RESEARCH PROCESS}

The idea of the official currency of the Internet is almost as old as the Internet itself, but the decline of trust in banking system after the subprime crisis is the main reason for the rapid emergence of alternative currency market (Chrabonszczewska, 2014, p. 51). Popularity of bitcoin among Internet users as well as the development of the Initial Coin Offering indicated the necessity of classification and defining bitcoin and similar digital assets functioning on the Internet. Successful, open-source bitcoin encourages people with certain IT skills to create their own currencies and tokens that may be used to finance illegal activities and launder money because their users can remain largely anonymous (Christopher, 2014, p. 10). That is the reason why organizations such as the Financial Action Task Force (FATF) and the European Central Bank (ECB) attempted to define virtual currencies for legislation purposes. Their classification is very similar. The ECB in its report "Virtual currency schemes" suggested that virtual currency is a response to virtual community needs for its own "money", or rather a currency that may have similar functions, allowing the members to exchange goods and services easily (European Central Bank, 2012, p. 5). The FATF defines virtual currency as "a digital representation of value that can be digitally traded and functions as (1) a medium of exchange; and/or (2) a unit of account; and/or (3) a store of value, but does not have legal tender status in any jurisdiction." (FATF, 2014, p. 4). Virtual currency and e-money (which is a digital version of a fiat currency) are digital currencies (FATF, 2014, p. 4). However, some academics claim that the term "virtual currency" should be replaced by "digital currency" because the word "virtual" has a negative connotation (Lee, 2015, p. 6). Among open virtual currencies (which will be 
defined in the next paragraph) there are some "math-based, decentralized and protected by cryptography" that are called cryptocurrencies (FATF, 2014, p. 5).

Virtual currency schemes can be closed or have either bidirectional or unidirectional flow. Closed virtual currency schemes imply that such currencies can be earned by conducting some activities within a community or a game and be spent only on these goods and services that are offered in the game (the community). It implicates that this kind of virtual currencies "has almost no link to the real economy" (European Central Bank, 2012, p. 13). The FATF distinguishes open and closed virtual currency schemes (FATF, 2014, p. 4). The open one has almost the same definition as the ECB's virtual currency scheme with bidirectional flow, which states that a virtual currency is convertible in both ways, unlike the unidirectional flow in which the fiat money can be converted into a virtual currency, but the virtual currency cannot be converted back into the fiat money (European Central Bank, 2012, pp. 13-15).

Some academics claim that definitions provided by the FATF and the ECB are incomplete because of the dynamic development of the cryptocurrency market. They highlight two main features of virtual currencies: digital form and no governmental control (Bala, Kopyściański \& Srokosz, 2016, pp. 52-53). In addition to being uncontrolled by monetary authorities it can be said that virtual currencies are not backed by any asset (Franco, 2015, p. 3), so they have value only because their users agree that they have value (Ali, Barrdear, Clews \& Southgate, 2014, p. 278) and are created by individuals and organizations, but not central banks (White, 2015, p. 383). The concern over a possible risk of the rising popularity of virtual currencies forced central banks to send a warning to citizens and companies. The National Bank of Poland in its official statement informs that virtual currencies are not money, currency or e-money, as they are not widely accepted as a form of payment (NBP, 2017). Despite such warnings and speculations on cryptocurrencies, some researchers consider virtual currencies as money existing online (Pacy, 2014, p. 122; Sauer, 2016, p. 118) or even a form of e-money (Ryfa, 2014, p. 141). The author of the idea, Satoshi Nakamoto, created the Bitcoin network for transferring electronic cash (Nakamoto, 2008, p. 1). Bitcoin operates as a medium of exchange in traditional shops and e-commerce, but yet, the medium of exchange is not money, although, as some academics claim, it may become one (Davidson \& Block, 2015, p. 312). Bitcoin and other virtual currencies are sometimes considered to be alternative money systems (Sobiecki, 2016, p. 151), which seems to correspond with Satoshi Nakamoto's idea. Being a response to ineffective and costly traditional 
transfer systems, Bitcoin seemed to be a great solution for those who wanted to transfer their money freely. Unfortunately, the Bitcoin system has its limits and because of them on the 1st August 2017 some of the unhappy users decided to start a hard fork. Since then Bitcoin has been divided into bitcoin and bitcoin cash (Kwiatek, 2017).

\section{THE INITIAL COIN OFFERING AS A FORM OF CAPITAL RISING}

The classification mentioned above may seem insufficient. Further analysis conducted by the European Central Bank and published in 2015 demonstrates that apart from using word "currency" in the term "virtual currency" those assets cannot be considered nor money, nor currency in terms of economic science and law, but only a digital representation of value that is not issued by any central bank or any financial institution, but, over some conditions, can be used as an alternative form of payment (European Central Bank, 2015, p. 4). This definition seems to correspond more strictly with cryptocurrencies and tokens issued within the ICO procedure. The similarity between the term the Initial Coin Offering and the Initial Public Offering is not accidental. Both methods are following the scheme of issuing some asset that can be treated as an investment, selling it and raising capital from the investors that have decided to purchase it. However, the differences are clearly visible. First of all, IPO is regulated in details by the law whereas ICO remains, so far, unregulated or regulated in an insufficient way. While IPO involves stocks or bonds, an issued token or cryptocurrency may have some features of stocks, bonds, vouchers or have no additional attributes at all (Bazan, 2018). It means, that their character can be purely speculative. That implicates another significant difference between IPO and ICO that are areas and the level of risk. Within ICOs, as some researchers claim, over $80 \%$ are a form of fraud. So called "scam" is a situation in which the capital is raised without an intention to accomplish the announced project (Dowlat, 2018). Investors and companies that decided to finance their activity by the ICO procedure must also deal with a legal risk, as starting ICO procedure may cause the need for individual law interpretations. Further differences between ICO and IPO are presented in table 1. 
Table 1. The main differences between the Initial Public Offering and the Initial Coin Offering

\begin{tabular}{|l|l|l|}
\cline { 2 - 3 } & \multicolumn{1}{c|}{ IPO } & \multicolumn{1}{c|}{ ICO } \\
\hline \hline Legal status & Detailed regulation & No regulation or insufficient one \\
\hline Securities type & Stocks and bonds & $\begin{array}{l}\text { Tokens that may have features } \\
\text { of particular types of securities } \\
\text { or being vouchers or having no } \\
\text { additional attributes at all }\end{array}$ \\
\hline Risk level & Moderate & $\begin{array}{l}\text { High (for the company and inve- } \\
\text { stors) }\end{array}$ \\
\hline Accessibility & $\begin{array}{l}\text { For large enterprises } \\
\text { For investors }\end{array}$ & $\begin{array}{l}\text { May be used by almost any company } \\
\text { Anyone who have internet access } \\
\text { can become an investor }\end{array}$ \\
\hline Costs & High & Moderate or low \\
\hline \hline
\end{tabular}

S o u r c e : own study.

The ICOs tokens can be divided into few groups (www1):

- Currency tokens that can be used as a form of payment (called sometimes "coins"),

- Utility tokens that allow holders to access products or services within a particular platform or network,

- Securities tokens which work as utility tokens, but additionally promise some investments returns (can be similar to bonds),

- Asset tokens that are a digital representation of an asset,

- Equity tokens that work like stocks and give their holders an ownership share in the issuer's capital,

- Reward tokens that function like loyalty points,

- Dividend tokens that allow the holder to receive a dividend on any company's token, but without being an owner of the company.

Taking into consideration the fact that so many types of ICOs tokens appeared on the market so far, it is possible to claim that without the proper regulation there is a possibility of further evolution of their features. Tokens can represent almost any thing that may have value for investors, legal as well as illegal ones.

After the explanation of tokens and virtual currencies it is important to introduce the ICO financing model. The first three steps can be followed simultaneously or in sequence. A company may use the services offered by enterpris- 
es that specialize in the Initial Coin Offering or adopt the procedure itself. The model includes the following stages (Bazan, 2018; Momoh, 2016):

- Whitepaper publication. A whitepaper should contain detailed information about the project to be carried out and the issue of tokens (amount of tokens, form of payment, additional features, time framework etc.),

- Token or cryptocurrency creation. It can be developed by using existing platforms, dedicated to such activities or by a company itself,

- ICO promotion. The most important and challenging part. It is clear that a well-promoted token can encourage more people to invest than a badly-promoted one. It should be emphasised that some of the social networks have forbidden ICO advertising, or are about to do it, in order to protect users from scams,

- Introduction of tokens for sale on a virtual currency exchange,

- Project implementation and providing additional services to the investors.

\section{THE CASE STUDY OF ETHEREUM PROJECT}

To present how the Initial Coin Offering may help to rise funds needed to set up a start-up it was decided to introduce the case study of the first company that used that method - Ethereum. The author of the project is Vitalik Buterin, who after working as a member of the Bitcoin community and being fascinated by the blockchain technology decided to found Ethereum. The Ethereum white paper was published in 2013 and contains the technical details of the platform. In 2014 Gavin Wood, who became a co-founder of the project, published the yellow paper that includes technical specification for the Ethereum Virtual Machine (www2). The idea of Ethereum project is to "allow anyone to write smart contracts and decentralized applications where they can create their own arbitrary rules of ownership, transaction formats and state transition functions" (Buterin, 2013, p. 13). Currently, the platform allows its users, among others, to create their own cryptocurrency or token that can be used within the Initial Coin Offering procedure. It can be said that Ethereum made its idea to raise capital one of their products.

To make the implementation of the project possible, Ethereum creators decided to launch a presale of the token called ether. An Ether served as a form of payment for the Ethereum Virtual Machine's work. The more simple and effective code is, the smaller amount of ether is needed. It is rightful to claim that 
the ether was a utility token. The official announcement was published on the Ethereum Blog on $22^{\text {nd }}$ of July 2014. The following rules about the presale were set (Buterin, 2014):

- There is no possibility for using or transferring the ether until the launch of the genesis block that is planned to happen in winter 2014-2015,

- The sale starts on $22^{\text {nd }}$ of July 2014 and will last 42 days, till $2^{\text {nd }}$ of September 2014,

- The start price for an ether is set of $2000 \mathrm{ETH}$ for $1 \mathrm{BTC}$, but after 14 days the price changes to the level of $1337 \mathrm{ETH}$ for $1 \mathrm{BTC}$,

- There is no guarantee of the value of ether as it is not a security but a product,

- Purchase is available through the official Ethereum website or by using a Python tool.

The Ethereum project's ICO procedure was successful but the company had to face many legal challenges in Switzerland and the United States to start the presale. The organisation received 31,591 BTC (around \$18,439,086) in exchange for about $60,102,216$ ether that stated $83.47 \%$ of the offered supply ( $w w w 2 ; w w w 3)$. However, Ethereum needed to pay the debt resulting from the necessity to hire legal advisors, which suggests that the cost of the ICO procedure can be in some cases significant. It makes the opinion that ICO is a cheap form of a capital rising not completely true. Legal costs are the main barrier to the use of ICO.

Ethereum decided to sell their tokens in exchange for bitcoins. However, it is possible for a company to receive traditional currency. That model of financing within ICO is less risky for an organisation, because of the level of volatility of an exchange rate. On the other hand, the use of cryptocurrencies allows investors to remain almost anonymously and may bring a company additional profits connected with the changes in cryptocurrencies' prices.

\section{DiSADVANTAGES AND ADVANTAGES OF USING ICO PROCEDURE}

The conducted analysis and the case study allows to enumerate the disadvantages and advantages of the application of the Initial Coin Offering procedure to raise capital. As it was presented in the case study the most challenging part of launching ICO is taking a legal advice as, depending on the country, the ICO can be banned, regulated or partly regulated by law. However, popularity of ICO generated an increased interest in regulation of the process, so there is 
a possibility that soon it will be easier for the organisations to follow the rules. Another disadvantage is the risk resulting from an insufficient demand for offered tokens. It can stem mainly from distrust, poor promotion or uninteresting project. As it is visible in the case study, even successful Ethereum could not sell all of the issued tokens. Application of ICO requires certain IT skills that can also be a challenge for the company's authorities. There is a possibility for using specially designed ICO platforms that facilitate launching a token, such as the above-mentioned Ethereum platform. However, some IT knowledge is still needed. Launching a sale on a cryptocurrency exchange can be burdened with a risk of a fraud. That is why the careful choice of it is a must.

Despite the importance of foregoing challenges, the ICO procedure can bring some opportunities to the company. First of all, a successful ICO allows to raise funds needed to accomplish the project. It might be a chance for these companies that cannot use the traditional methods of fundraising, such as loans or IPO. In some parts ICO is similar to crowdfunding. Almost anyone who has an internet access can become an investor. ICO empowers the organisation to reach investors that live all around the world and that is the main advantage it has over traditional finance methods. The organisation that launched an ICO procedure can gain image benefits, as it can be perceived as innovative.

The status of the level of costs remains unclear. The necessity to engage legal advisors may be costly, however, it depends on the level of ICO regulation in the particular country. ICO can be much cheaper than IPO, but more expensive and demanding than a loan. However, if an organisation decides to follow an ICO procedure by itself, it can reduce the costs of it significantly.

\section{ConClusions}

ICO has been present in economy since 2014 but in 2017 it became popular among organisations with bad and good will. That is the reason for the authorities to undertake actions which will help honest companies to use ICO and protect potential investors from frauds and scams. The ICO will not become widely used in an economy until proper regulations are introduced.

The case study of the Ethereum project pointed out the most important problems for a company interested in launching ICO. Depending on the level of legal regulation in the particular country and the company's will to obey the law, the cost of ICO may differ significantly. 
The Initial Coin Offering is challenging for the company not only because of technical and legal reasons, but also because of its controversial character. It has many advantages over traditional forms of capital raising, like the level of accessibility, but the unclear legal status makes it difficult for start-ups to use the procedure. However, it should be noticed that for the company which offers products and services connected with blockchain technology, the use of the Initial Coin Offering is a reasonable choice that allows to get publicity among people interested in cryptocurrency and blockchain and further, to reach potential partners and clients.

The differentiation of tokens and their similarity to well-known securities implies that the entrepreneurs noticed the necessity to provide additional features to attract potential investors. That suggests that investors are looking for a token that has some value by itself and is more than a purely speculative good. It is what distinguishes ICO market from cryptocurrency market.

\section{REFERENCES}

Ali, R., Barrdear, J., Clews, R., \& Southgate, J. (2014). The economics of digital currencies. Bank of England Quarterly Bulletin, Q3, 276-286.

Bala, S., Kopyściański, T., \& Srokosz, W. (2016). Kryptowaluty jako elektroniczne instrumenty płatnicze bez emitenta. Aspekty informatyczne, ekonomiczne i prawne. (Cryptocurrencies as electronic payment instruments without an issuer. IT, economic and legal aspects.) Wrocław: Wydawnictwo Uniwersytetu Wrocławskiego.

Bazan, W. (2018). Kryptowaluty - nowa możliwość zdobycia kapitału, (Cryptocurrencies - a new opportunity to raise capital.) http://www.rp.pl/Firma/301269991Kryptowaluty---nowa-mozliwosc-zdobycia-kapitalu.html (accessed 15.02.2018).

Buterin, V. (2013). Ethereum white paper. A next generation smart contract \& decentralized application platform, working paper, http://whitepaperdatabase.com/ ethereum-eth-whitepaper (accessed 13.05.2018).

Buterin, V. (2014). Launching the Ether Sale, working paper, http://blog.ethereum. org/2014/07/22/launching-the-ether-sale (accessed 13.05.2018).

Chrabonszczewska, E. (2014). Bitcoin - Nowa Wirtualna Globalna Waluta? (Bitcoin The New, Global Virtual Currency?) International Journal of Management and Economics, 40(1), 50-71. http:// dx.doi.org/10.2478/ijme-2014-0028.

Christopher, C.M. (2014). Whack-a-Mole: Why Prosecuting Digital Currency Exchanges Won't Stop Online Laundering. Lewis \& Clark Law Review, 18(1), 1-36.

Davidson, L., \& Block, W.E. (2015). Bitcoin, the Regression Theorem, and the Emergence of a New Medium of Exchange. Quarterly Journal of Austrian Economics, 18(3), 311-338 .

Dowlat, S. (2018). ICO Quality: Development \& Trading, http://medium.com/satisgroup/ico-quality-development-trading-e4fef28df04f (accessed 03.04.2018). 
ESMA (2017). ESMA alerts investors to the high risks of Initial Coin Offerings (ICOs), http://www.esma.europa.eu/sites/default/files/library/esma50-157-829_ico_statement_investors.pdf (accessed 13.05.2018).

European Central Bank (2012). Virtual currency schemes. Frankfurt am Main: European Central Bank.

European Central Bank (2015). Virtual currency schemes: a further analysis. Frankfurt am Main: European Central Bank.

FATF (2014). Virtual Currencies. Key Definitions and Potential AML/CFT Risks. Paris: FATF/OECD.

Franco, P. (2015). Understanding bitcoin: cryptography, engineering and economics. Chichester: Wiley.

Kwiatek, W. (2017). Podział Bitcoina - o co w tym chodzi? (Bitcoin split - what is it all about?) http://www.fxmag.pl/artykul/podzia-bitcoina-o-co-w-tym-chodzi (accessed 10.11.2017).

Lee, D. (Ed.) (2015). Handbook of digital currency: bitcoin, innovation, financial instruments, and big data. Amsterdam: Elsevier/AP. http://dx.doi.org/10.3905/jwm.2015.18.2.096.

Momoh, O. (2016). Initial Coin Offering (ICO), http://www.investopedia.com/terms/i/ initial-coin-offering-ico.asp (accessed 06.04.2018).

Nakamoto, S. (2008). Bitcoin: A Peer-to-Peer Electronic Cash System, http://bitcoin. org/bitcoin.pdf (accessed 10.05.2018).

NBP (2017). Komunikat Narodowego Banku Polskiego i Komisji Nadzoru Finansowego w sprawie „walut” wirtualnych, (Announcement of the National Bank of Poland and the Polish Financial Supervision Authority regarding virtual currencies.) http:// www.nbp.pl/home.aspx?f=/aktualnosci/wiadomosci_2017/ww-pl.html (accessed 10.11.2017).

Pacy, E.P. (2014). Tales from the Cryptocurrency: On Bitcoin, Square Pegs, and Round Holes. New England Law Review, 49(1), 121-144.

Ryfa, J. (2014). Waluty wirtualne - problem zdefiniowania i klasy fikacji nowego środka płatniczego. (Virtual Currency - the Problem of Defining and Classifying New Means of Payment.) Nauki o Finansach, 2(19), 138-147. http://dx.doi.org/10.15611/ nof.2014.2.08.

Sauer, B. (2016). Virtual Currencies, the Money Market, and Monetary Policy. International Advances in Economic Research, 22(2), 117-130. http://dx.doi.org/10.1007/ s11294-016-9576-x.

Sobiecki, G. (2016). Alternatywne systemy pieniężne w gospodarce współpracy (collaborative economy). (Alternative money systems in a collaborative economy.) In M. Poniatowska-Jaksch, R. Sobiecki (Ed.). Sharing economy (gospodarka współdzielenia). Warszawa: Oficyna Wydawnicza SGH - Szkoła Główna Handlowa w Warszawie.

White, L.H. (2015). The market for cryptocurrencies. Cato J., 35, 383-402. http://dx.doi. org/10.2139/ssrn.2538290.

(www1) Dividend Tokens, Explained, http://cointelegraph.com/explained/dividendtokens-explained (accessed 17.04.2018). 
(www2) History of Ethereum - Ethereum Homestead 0.1 documentation, http://www. ethdocs.org/en/latest/introduction/history-of-ethereum.html (accessed 13.05.2018).

(www3) Overview: Ethereum's initial public sale, http://keepingstock.net/overviewethereum-s-initial-public-sale-563c05e95501 (accessed 13.05.2018). 